\title{
Genetic characterization of complete open reading frame of glycoprotein $C$ gene of bovine herpesvirus 1
}

\author{
Saurabh Majumder, A. B. Pandey and M. A. Ramakrishnan \\ Division of Virology \\ Indian Veterinary Research institute, Izatnagar - 243122, Dist. Bareilly, Uttar Pradesh, India \\ Corresponding author: M. A. Ramakrishnan, email: maramakrishnan@gmail.com \\ Received: 30-07-2013, Revised: 18-09-2013, Accepted: 19-09-2013, Published online: 15-10-2013
}

doi: $10.14202 /$ vetworld.2013.897-900

How to cite this article: Majumder S, Pandey AB and Ramakrishnan MA (2013) Genetic characterization of complete open reading frame of glycoprotein C gene of bovine herpesvirus 1, Veterinary World 6(11): 897-900.

\begin{abstract}
Aim: To characterize one of the major glycoprotein genes viz., glycoprotein $\mathrm{C}(\mathrm{gC}$; UL44, unique long region 44) of bovine herpesvirus 1(BoHV1) of Indian origin at genetic and phylogenetic level.

Materials and Methods: A bovine herpesvirus 1 isolate viz., (BoHV1/IBR 216 II/ 1976/ India) maintained at Division of Virology, IVRI, Mukteswar was used for the current study. The DNA was extracted using commercial kit and the complete ORF of gC gene was amplified, cloned, and sequenced by conventional Sanger sequencing method. The sequence was genetically and phylogenetically analysed using various bioinformatic tools. The sequence was submitted in the Genbank with accession number Kc756965.

Results: The complete ORF of gC gene was amplified and sequenced. It showed $100 \%$ sequence homology with reference cooper strain of BoHV1 and divergence varied from $0 \%$ to $2.7 \%$ with other isolates of BoHV1. The isolate under study had divergence of 9.2\%, 13\%, 26.6\%, and 9.2\% with BoHV5 (Bovine herpesvirus 5), CvHV1 (Cervid herpesvirus 1), CpHV1 (Caprine herpesvirus 1), and BuHV1 (Bubaline herpesvirus 1), respectively.

Conclusion: This is the first genetic characterization of complete open reading frame (ORF) of glycoprotein C gene (UL44) of Indian isolate of BoHV1. The $\mathrm{gC}$ gene of BoHV1 is highly conserved among all BoHV1 isolates and it can be used as a target for designing diagnostic primers for the specific detection of BoHV1.
\end{abstract}

Key words: BoHV1, glycoprotein C, PCR, UL44.

\section{I ntroduction}

Bovine herpesvirus 1 (BoHV1), the causative agent of infectious bovine rhinotracheitis/infectious pustular vulvovaginitis (IBR/IPV), infects mainly cattle (both domestic as well as wild) and buffaloes, but sheep and goats, swine, yaks, mithuns, mink and ferrets are also affected [1-3]. BoHV1 causes mainly three clinical syndromes in affected cattle and buffalos viz. infectious bovine rhinotracheitis (IBR), infectious pustular vulvovaginitis (IPV), and infectious pustular balanopostitis (IPB) [4]. The virus may also cause mastitis, infertility, abortion and is an important causative agent of shipping fever [4].

The BoHV1 genome encodes 73 recognized open reading frames (ORFs) within a 135301 bp doublestranded DNA genome. Three subtype variants of BoHV1, designated BoHV1.1a, BoHV1.2a and BoHV1.2b, are recognized based on genomic DNA restriction endonuclease profiles and clinical observations [5]. 10 Ten genes code for glycoproteins and among them 6 are present in unique long (UL) region i.e. gK (UL53), gC (UL44), gB (UL27), gH (UL22),gM (UL10) and gI (UL1) and 4 are in unique short (US) region i.e. gG (US4), gD (US6),gI (Us7),

Copyright: The authors. This article is an open access article licensed under the terms of the Creative Commons Attribution License (http://creativecommons.org/licenses/by/2.0) which permits unrestricted use, distribution and reproduction in any medium, provided the work is properly cited.
$\mathrm{gE}$ (US8). Glycoprotein $\mathrm{C}(\mathrm{gC})$ is one of the major glycoproteins present in the envelope of virion and plasma membrane of virus infected cell [6]. It encodes a protein of 521 amino acids with 4 potential sites for addition of $\mathrm{N}$ linked oligosaccharide and a serine /threonine rich region (amino acid 32-92) for addition of $\mathrm{O}$ linked oligosaccharide. It induces neutralizing antibody response [6] and, is recognized by CD4+ and CD8+ T lymphocytes [6], and it is the major protein involved in attachment to heparin like receptor on tissue culture cells [7]. It was observed that residue 76 of BHV-1.1 $\mathrm{gC}$ is valine and residue 76 of BHV1.2 $\mathrm{gC}$ is glycine [8].

The disease was first reported by Mehrotra et al., in 1976 [9] . Since then the disease has been reported in several states. The disease was found to be more prevalent in exotic and crossbred cattle than in indigenous breeds. However, very few studies have been focussed on molecular characterization of Indian isolates of BoHV1. In fact, no complete sequence of any $\mathrm{ORF} / \mathrm{gene}$ is available for Indian isolates.

The present study describes the complete sequences of $\mathrm{gC}$ genes of BoHV1 which was isolated in 1976 from calf suffering from keratoconjunctivitis [9].

\section{Materials and Methods}

Cells and virus: Madin-Darby bovine kidney (MDBK) cells were grown in Dulbecco's Modified Eagle 
Medium + GlutaMax-I (Invitrogen, USA) with 10\% Newborn Calf Serum (Invitrogen, USA). The cells were incubated at $37^{\circ} \mathrm{C}$ in the presence of $5 \% \mathrm{CO} 2$. A BoHV1 isolate viz., (BoHV1/IBR 216 II/ 1976/ India) maintained at Division of Virology, IVRI, Mukteswar was used for the present study.

Extraction of viral DNA: The DNA was extracted using commercial kit as per the manufacture's instruction (Promega, USA). In brief, MDBK cells infected with BoHV1 when showing $80 \%$ CPE were harvested and supernatant discarded. The infected cell layer was added with $200 \mu \mathrm{L}$ of phosphate buffer saline (PBS) and thrice freeze-thawed $\left(30 \mathrm{~min}\right.$ each at $-80{ }^{\circ} \mathrm{C}$ and $37^{\circ} \mathrm{C}$ ). Then, $600 \mu \mathrm{L}$ of nuclei lysis solution was added to the above lysate and mixed by pipetting. To remove RNA, $3 \mu \mathrm{L}$ of RNase solution was added, mixed and incubated at $37^{\circ} \mathrm{C}$ for $30 \mathrm{~min}$. About $200 \mu \mathrm{L}$ of protein precipitation solution was added, vortexed and chilled on ice for $5 \mathrm{~min}$. The suspension was centrifuged at $13000 \mathrm{x} \mathrm{g}$ for $4 \mathrm{~min}$ and the supernatant was transferred to a new tube. To precipitate the DNA, about $600 \mu \mathrm{L}$ of isopropanol was added to the supernatant and centrifuged at $13000 \mathrm{x}$ g for $1 \mathrm{~min}$. After decanting the supernatant, about $600 \mu \mathrm{L}$ of $70 \%$ ethanol was added and centrifuging at $13000 \mathrm{xg}$ for $1 \mathrm{~min}$. After removing ethanol by aspiration and air drying, the DNA pellet was rehydrated with adding $100 \mu \mathrm{L}$ of rehydration solution and incubating for $1 \mathrm{~h}$ at $65^{\circ} \mathrm{C}$.

Polymerase chain reaction (PCR): Oligonucleotides primers were designed based on sequence of the reference strain of BoHV1 (Genbank accession ID JX898220.1.1). Set of primers was designed for full length amplification of glycoprotein $\mathrm{C}$ gene (gC-F-5'ATGGGCCCGCTGGGGCGAGC-3'; gC-R- 5' CTACAGGCGCGCCCGGGCCTTG-3)'. The PCR was carried out in a 50 L of total volume of reaction mixture containing $25 \mu \mathrm{L}$ of $2 \mathrm{X}$ Maxima ${ }^{\circledR}$ Hot start Green PCR Master Mix (Fermentas, USA), $5 \mu \mathrm{L}$ of glycerol (Amresco, USA), $1 \mu \mathrm{L}$ of forward primer $(0.2$

$\mathrm{M}$ final conc.), $1 \mu \mathrm{L}$ of reverse primer $(0.2 \mathrm{M}$ final conc.), $1 \mu \mathrm{L}$ of template DNA and nuclease free water to $50 \mathrm{~L}$. The resulting mixture was subjected to a precise thermal profile as follows: $95^{\circ} \mathrm{C}$ for 5 minutes; 35 cycle at $95{ }^{\circ} \mathrm{C}$ for 1 minute, $55^{\circ} \mathrm{C}$ for 1 minute, 72 ${ }^{\circ} \mathrm{C}$ for 1.5 minutes followed by one cycle at $72{ }^{\circ} \mathrm{C}$ for 10 minutes. Expected band size was visualized using ultraviolet transilluminator after running 5 L of PCR product in 1\% agarose gel. PCR amplicons of expected size was gel purified (QIAquick® Gel Extraction Kit, Qiagen, USA) and used for downstream applications.

Cloning and sequencing: The gel purified PCR amplicon was cloned using InsTA cloning Kit (Fermentas, USA). In brief, $1 \mu \mathrm{L}$ of vector pTZ57R/T was mixed with $1 \mu \mathrm{L}$ 10X Ligation buffer, $4 \mu \mathrm{L}$ purified PCR product, $1 \mu \mathrm{L}$ T4 DNA Ligase and nuclease free water was added to $10 \mu \mathrm{L}$. The mixture was vortexed, centrifuged for 3-5 sec and incubated for $2.5 \mathrm{~h}$ at $22{ }^{\circ} \mathrm{C}$ followed by for overnight at $4^{\circ} \mathrm{C}$. For transformation, $50 \mu \mathrm{L}$ of competent DH5 $\alpha$ from $-80^{\circ} \mathrm{C}$ was thawed on ice and Mixed with $5 \mu \mathrm{L}$ of ligated PCR product and kept on ice for $30 \mathrm{~min}$. The mixture was subjected to heat shock at $42{ }^{\circ} \mathrm{C}$ for $1 \mathrm{~min}$, followed by $2 \mathrm{~min}$ on ice. $1 \mathrm{~mL}$ of LB broth was added to the tube and mixed by inversion, and incubated at $37^{\circ} \mathrm{C}$ in a shaker incubator for $2 \mathrm{~h}$. The cells were centrifuged at $5000 \mathrm{rpm}$ for $2 \mathrm{~min}$; the pellet was reconstituted in $50 \mu \mathrm{L}$ of PBS and spreaded over Luria Bertani (LB) agar plate containing ampicillin (50 $\mu \mathrm{g} / \mathrm{mL})$, X-gal $(30 \mu \mathrm{g} / \mathrm{mL})$ and Isopropyl $\beta$-D-1thiogalactopyranoside (IPTG, $40 \mu \mathrm{g} / \mathrm{mL}$ ). The plate was incubated at $37^{\circ} \mathrm{C}$ for overnight at upright position. At least ten white colonies were selected and confirmed for having the desired construct by colony PCR using M13 and gene specific primers. The confirmed bacterial containining positive inserts were commercially sequenced (SciGenome, Cochin, Kerala).

Sequence trimming and editing of the raw sequence was carried out using Sequencher 4.9 (Gene Codes Corporation, MI, USA). References sequences includes BoHV1 isolates and other members of Alphaherpesvirinae were downloaded from GenBank. The $\mathrm{gC}$ gene sequence of the Indian isolate and references sequences were aligned using the MEGA 5 software [10]. The phylogenetic tree was constructed using neighbor-joining algorithm with Kimura-2 parameters correction and 1000 bootstrap replications.

\section{Results and Discussion}

To amplify complete ORF of gC gene, glycerol @ $5 \%$ has been added in PCR reaction. Without adding glycerol, no amplification could be obtained with different manufactures' enzymes and/or PCR conditions. It is difficult to amplify sequences having high $\mathrm{G}+\mathrm{C}$ contents (guanine-cytosine content) because of the low efficiency of template dissociation due to alteration in the melting point of the DNA template [11]. Several researchers used glycerol in PCR mixtures to enhance the speci? city and/or the yield of the PCR from high GC templates [12]. The G+C content of BoHV1 ranges from 71-72\% [13]. Glycerol helps in strand-separation and primer-annealing temperatures and also reduces secondary structure that could inhibit the progress of the polymerase. It lowers the temperature of strand separation by lowering the concentration of water, thus the dielectric constant, thus the force needed for breaking Hydrogen-bridges (http://worldwide.promega.com/resources/productguides-and-selectors/protocols-and-applicationsguide/pcr-amplification/). The results are in accordance with the previous reports of use of glycerol for amplification of BoHV1 genes [12,13].

On agarose gel electrophoresis of PCR product, an expected band size of $\sim 1527$ bp could be visualized (Figure-1). Sequencing of the cloned product also confirms that the length of the $\mathrm{gC}$ gene of the isolate studied is 1527 bases (Accession No. KC756965) as that reference Cooper strain. Sequence identity of the product was reconfirmed by blasting in NCBI blast. It 


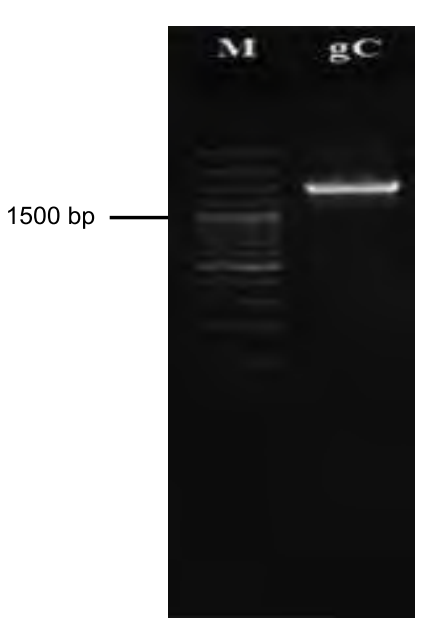

Figure-1. Result of colony PCR for confirmation of presence of amplified glycoprotein C gene insert using universal M13 primers.

Lane 1: 100 bp plus DNA marker Lane 2: Colony PCR product

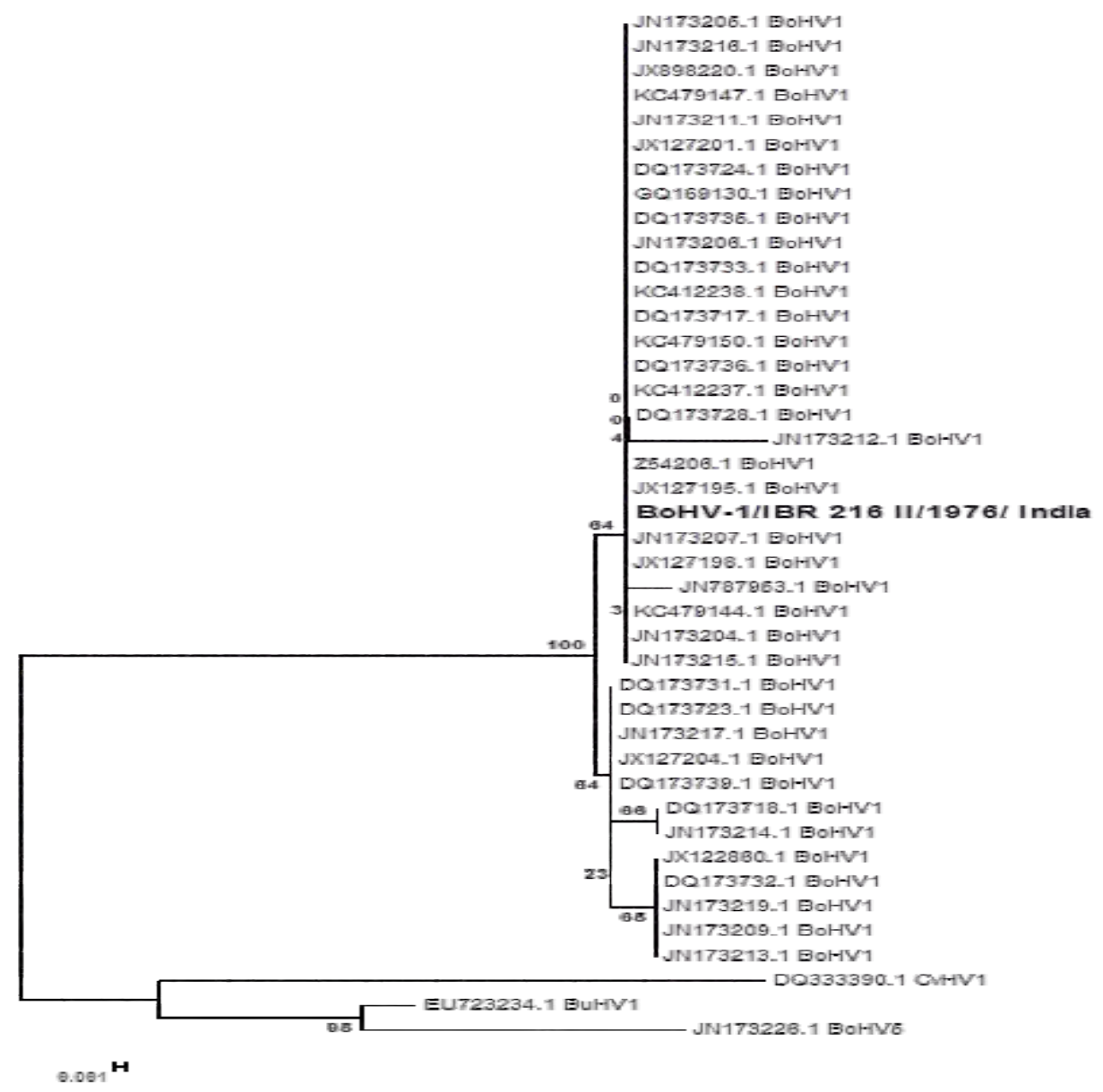

Figure-2. Phylogenetic analysis of glycoprotein C gene of various isolates of BoHV1 with other related members of Alphaherpesvirinae showed $100 \%$ sequence homology with Cooper strain (Genbank accession ID JX898220.1.1) and divergence varied from $0 \%$ to $2.7 \%$ with other BoHV1 isolates. The Indian isolate had divergence of $9.2 \%, 13 \%$, $26.6 \%$, and $9.2 \%$ with BoHV5, CvHV1, CpHV-1, and BuHV1, respectively.

In the deduced amino acid analysis, Indian isolate of the current study has valine at position 76 of $\mathrm{gC}$ gene. It was reported that the amino acid position 76 of $\mathrm{gC}$ is an marker for differentiating BoHV1.1 (valine) and BoHV1.2 (glycine) [8]. In the present study, available $\mathrm{gC}$ gene sequences of all BoHV1 isolates were downloaded and multiple alignment was carried out. At nucleotide position 1104, all the BoHV1 subtype 1.1 isolates had T whereas BoHV subtype 1.2 isolates had $\mathrm{C}$ at this position. Based on the above observations, the Indian isolate under study was classified under subtype BoHV1.1. In this isolate four $\mathrm{N}$ - glycosylation sites were present at amino acid position 93, 111, 164 and 208 which is in accordance with previous reports [14]. The N-glycosylation of viral glycoprotein plays an important role in stability, antigenicity and host cell invasion of the virus [15].

Phylogenetic analysis of $\mathrm{gC}$ gene revealed that all BoHV1 isolates including under study are clustered within single clade. The CvHV1, CpHV1, and BoHV5 viruses formed individual clusters with respective viruses. In conclusion, this is the first genetic characterization of complete ORF of glycoprotein C gene (UL44) of Indian isolate of BoHV1. This study will lay foundation stone for further studies on BoHV1 in respect of development of vaccine or new diagnostics.

\section{Conclusion}

This is the first genetic characterization of complete ORF of glycoprotein C gene (UL44) of Indian isolate of BoHV1. Addition of glycerol is essential for amplifying GC rich portion of BoHV1 genome. Glycoprotein C gene of BoHV1 is highly conserved in all the isolates and it can be used as a target for designing of primers for diagnosis of IBR.

\section{Authors' contributions}

SM, ABP and MAR implemented the study design. SM and MAR carried out the work and analyses part. All authors drafted and revised the manuscript. All authors read and approved the final manuscript.

\section{Acknowledgements}

The authors thank the Director, Indian veterinary research institute, Izatnagar, Uttar Pradesh, India for providing the fund and the facilities to carry out the work. SMreceived fellowship from IVRI during the study.

\section{Competing interests}

The authors declare that they have no competing interests 


\section{References}

1. Whetstone CA, Evermann JF (1988) Characterization of bovine herpesviruses isolated from six sheep and four goats by restriction endonuclease analysis and radioimmunoprecipitation. Am J Vet Res 49:781-785.

2. Qu XY, Li CH (1988) Studies on diagnosing infectious bovine rhinotracheitis in yak by ELISA. China J Vet Sci Tech 3:5-8.

3. Rajkhowa S, Rajkhowa C, Rahman H, Bujarbaruah KM (2004) Seroprevalence of infectious bovine rhinotracheitis in mithun (Bos frontalis) in India. Rev Sci Tech 23:821-829.

4. Nandi S, Kumar M, Manohar M, Chauhan RS (2009) Bovine herpes virus infections in cattle. Anim Health Res Rev 10:85-98.

5. Spiliki FR, Esteves PA, Lima MD, Franco AC, Chiminazzo C, Flores EF, Weilblen R, Driemeier D, Roehe PM (2004) Comparative pathogenecity of Bovine herpesvirus 1 (BHV1) subtype 1 (BHV-1.1) and 2a (BHV-1.2a). Pesq Vet Bras 24:43-49.

6. Anonymous (2005) The biology of bovine herpesvirus 1 (BoHV-1). Department of Health and Ageing, Office of the gene technology regulator, Australian government 1-15.

7. Traesel CK, e Silva MS, Spilki FR, Weiblen R, Flores EF (2013) Nucleotide sequencing and phylogenetic analysis of the 3' region of glycoprotein $\mathrm{C}$ gene of South American bovine herpesviruses 1 and 5. Res Vet Sci 94:178-185.

8. Rijsewijk FA, Kaashoek MJ, Langeveld LD, Meloen R,
Judek J, Bienkowska-Szewczyk K, Maris-Veldhuis MA, Van orischot J T (1999) Epitopes on glycoprotein C of bovine herpesvirus-1 (BHV-1) that allow differentiation between BHV-1.1 and BHV-1.2 strains. J Gen Virol 80:1477-1483.

9. Mehrotra ML, Rajya BS, Kumar S (1976) Infectious bovine rhinotracheitis (IBR) - keratoconjunctivitis in calves. Indian J Vet Pathol 1:70-73.

10. Tamura K, Peterson D, Peterson N, Stecher G, Nei M, Kumar S (2011) MEGA5: molecular evolutionary genetics analysis using maximum likelihood, evolutionary distance, and maximum parsimony methods. Mol Biol Evol 28: 2731-2739.

11. Ros C, Belák S (1999) Studies of genetic relationships between bovine, caprine, cervine, and rangiferine alpha herpesviruses and improved molecular methods for virus detection and identification. J Clin Microbiol 37:1247-1253.

12. Gupta PK, Saini M, Rai A (2006) Rapid and sensitive PCRbased test for detection of bovine herpesvirus-1 in semen. Indian Jvirol 17:23-27.

13. Nandi S, Kumar S (2011) Improved efficiency of the polymerase chain reaction for detection of bovine herpesvirus-1 genomic DNA. Buffalo bulletin 30: 250-255.

14. Chowdhury SI (1995) Molecular basis of antigenic variation between the glycoproteins $\mathrm{C}$ of respiratory bovine herpes virus 1 (BHV-1) and neurovirulent BHV-5. Virology 213: 558-568.

15. Vigerust DJ, Shepherd VL (2007) Virus glycosylation: role in virulence and immune interactions. Trends Microbiol $15: 211-218$.

$* * * * * * * *$ 